\title{
Phytoprotection
}

\section{Distribution of plant-parasitic nematodes in strawberry and raspberry fields in Quebec}

\section{G. Bélair et S. Khanizadeh}

Volume 75, numéro 2, 1994

URI : https://id.erudit.org/iderudit/706056ar

DOI : https://doi.org/10.7202/706056ar

Aller au sommaire du numéro

Éditeur(s)

Société de protection des plantes du Québec (SPPQ)l

ISSN

0031-9511 (imprimé)

1710-1603 (numérique)

Découvrir la revue

Citer cet article

Bélair, G. \& Khanizadeh, S. (1994). Distribution of plant-parasitic nematodes in strawberry and raspberry fields in Quebec. Phytoprotection, 75(2), 101-107. https://doi.org/10.7202/706056ar
Résumé de l'article

Afin de connaître les nematodes phytoparasites associés au fraisier \{Fragariax ananassa) et au framboisier (Rubus idaeus) dans sept régions agricoles du Québec (Cantons de l'Est, L'Assomption, Mauricie, Nicolet, Québec, Richelieu et Saint-Jean), 213 échantillons de sol ont été récoltés et analysés en juin et en juillet 1980. Le genre Pratylenchus fut le plus communément rencontré, soit dans $56,3 \%$ des champs de fraise et $46,4 \%$ des champs de framboise échantillonnés. Les densités de population du genre Pratylenchus étaient négativement corrélées avec les densités du Meloidogynehapla et le pH du soil. Le Paratylenchus était absent des champs de fraise des régions de Richelieu et de la Mauricie. Le $M$. hapla a été relevé dans des champs de fraise des régions de L'Assomption, Nicolet, Québec et Saint-Jean, et dans des champs de framboise des régions de Québec et de Saint-Jean. La présence du genre Xiphinema a été observée uniquement dans un champ de framboise des Cantons de l'Est. Les genres Tylenchus, Tylenchorhynchus et Helicotylenchus n'ont pas été observés dans la framboise. Les régions agricoles ont été divisées en groupes homogènes en fonction de leur distribution de nematodes, telle que révélée par une analyse en grappe. 


\title{
Distribution of plant-parasitic nematodes in strawberry and raspberry fields in Quebec
}

\author{
Guy Bélair ${ }^{1}$ and Shahrokh Khanizadeh ${ }^{1,2}$
}

Received 1993-09-14; accepted 1994-11-01

In a survey of plant-parasitic nematodes associated with strawberry (Fragaria x ananassa) and raspberry (Rubus idaeus) in seven Quebec agricultural regions (Eastern Townships, L'Assomption, Mauricie, Nicolet, Québec, Richelieu, and Saint-Jean), 213 soil samples were analyzed in June and July 1980. The most commonly encountered nematode genus was Pratylenchus, occurring in $56.3 \%$ and $46.4 \%$ of sampled strawberry and raspberry fields, respectively. The population density of Pratylenchus was negatively correlated with that of Meloidogyne hapla and with soil pH. No Paratylenchus was found in raspberry fields from the Mauricie and Richelieu regions. M. hapla was found in strawberry fields of the L'Assomption, Nicolet, Québec and Saint-Jean regions, and also in raspberry fields in the Québec and Saint-Jean regions. The genus Xiphinema was recorded in only one raspberry field in the Eastern Townships. Tylenchus, Tylenchorhynchus and Helicotylenchus were not found on raspberry. Agricultural regions were divided into homogeneous groups with respect to their nematode distribution as revealed by cluster analysis.

Bélair, G. et S. Khanizadeh. 1994. Distribution des nématodes phytoparasites dans les champs de fraise et de framboise au Québec. PHYTOPROTECTION 75: 101-107.

Afin de connaître les nématodes phytoparasites associés au fraisier (Fragaria x ananassa) et au framboisier (Rubus idaeus) dans sept régions agricoles du Québec (Cantons de I'Est, L'Assomption, Mauricie, Nicolet, Québec, Richelieu et Saint-Jean), 213 échantillons de sol ont été récoltés et analysés en juin et en juillet 1980. Le genre Pratylenchus fut le plus communément rencontré, soit dans $56,3 \%$ des champs de fraise et $46,4 \%$ des champs de framboise échantillonnés. Les densités de population du genre Pratylenchus étaient négativement corrélées avec les densités du Meloidogyne hapla et le $\mathrm{pH}$ du soil. Le Paratylenchus était absent des champs de fraise des régions de Richelieu et de la Mauricie. Le $M$. hapla a été relevé dans des champs de fraise des régions de L'Assomption, Nicolet, Québec et Saint-Jean, et dans des champs de framboise des régions de Québec et de Saint-Jean. La présence du genre Xiphinema a été observée uniquement dans un champ de framboise des Cantons de l'Est. Les genres Tylenchus, Tylenchorhynchus et Helicotylenchus n'ont pas été observés dans la framboise. Les régions agricoles ont été divisées en groupes homogènes en fonction de leur distribution de nématodes, telle que révélée par une analyse en grappe.

1. Agriculture and Agri-Food Canada, Horticulture research and Development Centre, 430, Gouin blvd., Saint-Jean-sur-Richelieu, Quebec, Canada J3B 3E6. Contribution No 335/94.10.02R

2. Department of Plant Science, Macdonald Campus of McGill University, Sainte-Anne-deBellevue, Quebec, Canada H9X 3V9 


\section{INTRODUCTION}

Quebec is a major berry-producing area in eastern Canada with $11263 \mathrm{t}$ of strawberry (Fragaria $x$ ananassa Duch.) and 931 t of raspberry (Rubus idaeus L.) for a \$26 million crop return annually (Statistics Canada 1992). These two small fruit crops are produced on a wide range of soil types with different cultural practices. While some growers are unaware of nematode problems, others use nematicides on a routine basis. Root-lesion nematodes (Pratylenchus spp.) and root-knot nematodes (Meloidogyne hapla (hitwood) have been isolated from strawberry and raspberry fields from soil samples processed through the Nematology Advisory Service (Agriculture and Agri-Food Canada). However, extensive surveys had not been conducted to date in Quebec berry-producing areas.

Surveys conducted from 1972-1979 in the province have identified the major plant-parasitic nematodes on apple (Malus pumila Borkh.), tobacco (Nicotiana tabacum L.), forage and vegetable crops (Meloche et al. 1980; Santerre and Lévesque 1982; Vrain and Dupré 1982; Vrain and Rousselle 1980; Willis et al. 1976). In most agricultural regions, the root-lesion nematode, Pratylenchus spp., was the most dominant genus, occasionally reaching damaging population densities.

This survey was conducted to determine the density and distribution of plant-parasitic nematodes in the major berry-producing areas of Quebec; to assess any possible correlation between the densities of these organisms and specific abiotic variables recorded in this survey; and to determine any similarities between agricultural regions in terms of nematode types and densities.

\section{MATERIALS AND METHODS}

During June and July 1980, a total of 213 soil samples were recovered from 185 strawberry and 28 raspberry fields in a survey covering the seven major berry-producing areas in Quebec (Eastern Townships, L'Assomption,
Mauricie, Nicolet, Québec, Richelieu, and Saint-Jean). Although fields were not selected using strict random procedure, no effort was made to select fields with conspicuous problems. Ten to fifteen soil subsamples $(0-20 \mathrm{~cm}$ deep) taken at random in the row with a hand trowel were combined to form a composite sample for each field of 0.2-0.8 ha. Soil samples were put into plastic bags and stored at $10-15^{\circ} \mathrm{C}$ until needed.

Nematode soil densities were determined by extracting nematodes from a $100-\mathrm{cm}^{3}$ subsample using the modified Baermann funnel method (Townshend 1963). Identification to genus and nematode counts were made using a stereomicroscope. Specific identifications were verified by Dr. R.V. Anderson, Biosystematics Research Center, Ottawa, Ontario. Nematode counts were transformed to $\log (x+2)$ prior to analysis as proposed by Proctor and Marks (1974) and soil samples were analyzed for sand fraction (Bouyoucos 1962). Soil $\mathrm{pH}$ and organic content were determined by using standard procedures (McKeague 1977).

Simple statistics (mean, maximum, and frequency) and cluster analysis were performed on nematode counts using SAS (SAS Institute Inc. 1988). The cluster analysis was used to distinguish clusters of regions that have similar attributes with respect to nematode genera and density. Arcsine transformation of percentages were used prior to analysis when needed.

\section{RESULTS}

Eight genera of stylet-bearing nematodes were isolated from strawberry soils and six genera were isolated from raspberry soils in Quebec (Tables 1, 2). The root-lesion nematodes Pratylenchus penetrans Cobb and P. crenatus Loof were the most conspicuous plarit-parasitic nematodes associated with these crops, and were present in $56.3 \%$ and $46.4 \%$ of sampled strawberry and raspberry fields, respectively. Of the soil samples infested with Pratylenchus spp., $94.0 \%$ had $P$. penetrans, $7.7 \%$ had $P$. crenatus, and only $1.7 \%$ had both species. 
The northern root-knot nematode, Meloidogyne hapla, was found in $11.9 \%$ and $7.1 \%$ of the sampled strawberry and raspberry fields, respectively. When present, $M$. hapla was found in greater population densities in raspberry than in strawberry. M. hapla was not found in soil samples from the Eastern Town- ships, Mauricie and Richelieu regions, neither in raspberry fields in L'Assomption and Nicolet. The pin nematode, Paratylenchus spp., was the most numerous plant-parasitic nematode in all tested strawberry fields. Paratylenchus spp. was not found in raspberry fields in the Mauricie and Richelieu

Table 1. Number of fields, mean and maximum density of plant-parasitic nematodes, and frequency of infestation in 185 strawberry fields in seven agricultural regions of the Quebec province

\begin{tabular}{|c|c|c|c|c|c|c|c|c|c|}
\hline Agricultural region & $\begin{array}{c}\text { Eastern } \\
\text { Townships }\end{array}$ & L'Assomption & Mauricie & Nicolet & Québec & Richelieu & Saint-Jean & $\begin{array}{l}\text { Overall mean } \\
\text { and total } \\
\text { frequency }\end{array}$ & $\begin{array}{c}\text { Total } \\
\text { infested fields } \\
(\%)\end{array}$ \\
\hline$N^{a}$ & 13 & 57 & 10 & 12 & 65 & 9 & 19 & & \\
\hline \multicolumn{10}{|c|}{ Pratylenchus spp. } \\
\hline Mean $^{b}$ & 53 & 26 & 46 & 52 & 38 & 5 & 13 & 33 & \\
\hline Maximum $^{b}$ & 180 & 300 & 120 & 290 & 238 & 10 & 28 & & \\
\hline Frequency ${ }^{c}$ & 11 & 27 & 8 & 8 & 43 & 4 & 3 & 104 & 56.3 \\
\hline \multicolumn{10}{|c|}{ Meloidogyne spp. } \\
\hline Mean & 0 & 10 & 0 & 28 & 7 & 0 & 3 & 7 & \\
\hline Maximum & 0 & 22 & 0 & 28 & 14 & 0 & 4 & & \\
\hline Frequency & 0 & 10 & 0 & 1 & 9 & 0 & 2 & 22 & 11.9 \\
\hline \multicolumn{10}{|c|}{ Paratylenchus spp. } \\
\hline Mean & 93 & 11 & 25 & 176 & 8 & 4 & 7 & 46 & \\
\hline Maximum & 350 & 30 & 70 & 590 & 16 & 4 & 12 & & \\
\hline Frequency & 4 & 8 & 4 & 4 & 6 & 1 & 4 & 31 & 16.8 \\
\hline \multicolumn{10}{|c|}{ Tylenchus spp. } \\
\hline Mean & 0 & 5 & 6 & 0 & 34 & 0 & 0 & 6 & \\
\hline Maximum & 0 & 5 & 6 & 0 & 120 & 0 & 0 & & \\
\hline Frequency & 0 & 2 & 1 & 0 & 4 & 0 & 0 & 7 & 3.8 \\
\hline \multicolumn{10}{|c|}{ Trichodorus spp. } \\
\hline Meanb & 0 & 6 & 0 & 0 & 7 & 15 & 0 & 4 & \\
\hline Maximum & 0 & 8 & 0 & 0 & 12 & 26 & 0 & & \\
\hline Frequency & 0 & 3 & 0 & 0 & 3 & 2 & 0 & 8 & 4.3 \\
\hline \multicolumn{10}{|c|}{ Tylenchorhynchus spp. } \\
\hline Mean & 4 & 11 & 0 & 0 & 0 & 0 & 0 & 2 & \\
\hline Maximum & 43 & 16 & 0 & 0 & 0 & 0 & 0 & & \\
\hline Frequency & 1 & 2 & 0 & 0 & 0 & 0 & 0 & 3 & 1.6 \\
\hline \multicolumn{10}{|c|}{ Helicotylenchus spp. } \\
\hline Mean & 0 & 0 & 0 & 0 & 4 & 0 & 0 & 1 & \\
\hline Maximum & 0 & 0 & 0 & 0 & 4 & 0 & 0 & 4 & \\
\hline Frequency & 0 & 0 & 0 & 0 & 1 & 0 & 0 & 1 & 0.5 \\
\hline \multicolumn{10}{|c|}{ Ditylenchus spp. } \\
\hline Mean & 0 & 4 & 4 & 0 & 3 & 4 & 2 & 2 & \\
\hline Maximum & 0 & 4 & 4 & 0 & 3 & 4 & 2 & 17 & \\
\hline Frequency & 0 & 2 & 1 & 0 & 1 & 1 & 1 & 6 & 3.2 \\
\hline
\end{tabular}


Table 2. Number of fields, mean and maximum density of plant-parasitic nematodes, and frequency of infestation in 28 raspberry fields in seven agricultural regions of the Quebec province

\begin{tabular}{|c|c|c|c|c|c|c|c|c|c|}
\hline Agricultural region & $\begin{array}{c}\text { Eastern } \\
\text { Townships }\end{array}$ & L'Assomption & Mauricie & Nicolet & Québec & Richelieu & Saint-Jean & $\begin{array}{l}\text { Overall mean } \\
\text { and total } \\
\text { frequency }\end{array}$ & $\begin{array}{c}\text { Total } \\
\text { intested fields } \\
(\%)\end{array}$ \\
\hline $\mathrm{N}^{\mathrm{a}}$ & 4 & 12 & 1 & 1 & 3 & 2 & 5 & & \\
\hline \multicolumn{10}{|c|}{ Pratylenchus spp. } \\
\hline Mean $^{\mathrm{b}}$ & 45 & 12 & 12 & 5 & 12 & 26 & 34 & 21 & \\
\hline Maximumb & 88 & 20 & 12 & 5 & 12 & 32 & 40 & & \\
\hline Frequency $^{c}$ & 3 & 3 & 1 & 1 & 1 & 2 & 2 & 13 & 46.4 \\
\hline \multicolumn{10}{|c|}{ Meloidogyne spp. } \\
\hline Mean & 0 & 0 & 0 & 0 & 48 & 0 & 42 & 13 & \\
\hline Maximum & 0 & 0 & 0 & 0 & 48 & 0 & 42 & & \\
\hline Frequency & 0 & 0 & 0 & 0 & 1 & 0 & 1 & 2 & 7.1 \\
\hline \multicolumn{10}{|c|}{ Paratylenchus spp. } \\
\hline Mean & 22 & 69 & 0 & 4 & 200 & 0 & 18 & 45 & \\
\hline Maximum & 35 & 138 & 0 & 4 & 200 & 0 & 21 & & \\
\hline Frequency & 2 & 3 & 0 & 1 & 1 & 0 & 2 & 9 & 32.1 \\
\hline \multicolumn{10}{|c|}{ Trichodorus spp. } \\
\hline Mean & 2 & 0 & 0 & 0 & 0 & 0 & 0 & 0.3 & \\
\hline Maximum & 2 & 0 & 0 & 0 & 0 & 0 & 0 & & \\
\hline Frequency & 1 & 0 & 0 & 0 & 0 & 0 & 0 & 1 & 3.6 \\
\hline \multicolumn{10}{|c|}{ Ditylenchus spp. } \\
\hline Mean & 15 & 0 & 0 & 0 & 0 & 0 & 0 & 2 & \\
\hline Maximum & 15 & 0 & 0 & 0 & 0 & 0 & 0 & & \\
\hline Frequency & 1 & 0 & 0 & 0 & 0 & 0 & 0 & 1 & 3.6 \\
\hline \multicolumn{10}{|c|}{ Xiphinema spp. } \\
\hline Mean & 250 & 0 & 0 & 0 & 0 & 0 & 0 & 36 & \\
\hline Maximum & 250 & 0 & 0 & 0 & 0 & 0 & 0 & & \\
\hline Frequency & 1 & 0 & 0 & 0 & 0 & 0 & 0 & 1 & 3.6 \\
\hline
\end{tabular}

\footnotetext{
a Number of fields sampled in each agricultural region.

b Number of nematodes in $100 \mathrm{~cm}^{3}$ of soil.

c Number of infested fields.
}

regions. No information is presently available on the pathogenicity of this ectoparasitic genus on raspberry and strawberry plants. No Tylenchus spp., Tylenchorhynchus spp. and Helicotylenchus spp. were observed in raspberry soil samples collected. Trichodorus spp. and Ditylenchus spp. were found in a raspberry field in the Eastern Townships. Xiphinema rivesi Dalmasso was confined to only one raspberry field in the Eastern Townships and was not observed in any strawberry fields. Tylenchus spp. was associated with strawberry fields in the L'Assomption, Mauricie and Québec regions (Table 1).
Trichodorus spp. was found only in strawberry fields in the L'Assomption, Québec and Richelieu regions. Tylenchorhynchus spp. was observed in the Eastern townships and L'Assomption, and Helicotylenchus spp. was observed in strawberry fields in the Québec region. Ditylenchus spp. was not observed in strawberry fields in the Eastern Townships and Nicolet regions.

Significant correlations were detected among abiotic variables and nematode densities. The population density of Pratylenchus spp. was negatively correlated with $M$. hapla $(r=-0.26$; 
$P<0.01)$ and with soil $\mathrm{pH}(\mathrm{r}=-0.23$; $P<0.01)$ but was positively correlated $(r=0.19 ; P<0.05)$ with Paratylenchus spp. The number of Paratylenchus spp. was positively correlated $(r=0.15$; $P<0.05)$ with the organic matter content. No significant correlation was established between plant-parasitic nematodes and sand content $(r=-0.06$; $P>0.05)$.

Cluster analysis revealed that the seven regions can be divided into two homogeneous groups with respect to the nematode distribution in strawberry fields. Group 1 consists of the Eastern Townships, Mauricie, and Nicolet regions and group 2 consists of the L'Assomption, Richelieu, Saint-Jean, and Québec regions (Fig. $1 A$ ). A similar procedure was applied to the data collected from raspberry fields. The seven agricultural regions were also divided into two groups: group 1 comprising Québec and the Eastern Townships and group 2 comprising all other regions (Fig. 1B).

\section{DISCUSSION}

Pratylenchus spp. is by far the most dominant plant-parasitic nematode both on strawberry and raspberry in Quebec. $P$. penetrans and $P$. crenatus were found in association but $P$. penetrans prevailed. This widespread distribution of Pratylenchus spp. in all agricultural regions is consistent with results from earlier surveys of apple orchard and vegetable crops in Quebec (Vrain and Dupré 1982; Vrain and Rousselle 1980). Nematicide treatments provided evidence that $P$. penetrans populations can impair growth and yield of raspberry and strawberry in Eastern Canada (Bélair 1991; Kimpinski 1985).

The northern root-knot nematode, $M$. hapla, also shown to be pathogenic to both strawberry and raspberry (McElroy 1972), is present on both crops in four agricultural regions. A similar proportion of $M$. hapla infested soils was found in vegetable fields of southern Quebec (Vrain and Dupré 1982). Because M. hapla soil population densities drop annually below the detection level in
July (G. Bélair, unpublished data), the actual distribution of this nematode may have been underestimated in this survey.

The dagger nematode, Xiphinema spp., was not isolated from strawberry fields but was isolated from one raspberry field from the Eastern Townships region where small fruits are occasionally grown on apple orchard soils. A nematological survey of Quebec orchards revealed the widespread distribution of $X$. rivesi in all appleproducing areas. In Quebec, there is some indication that $X$. rivesi could be associated with raspberry decline (Bélair 1991).

Correlations between nematode and abiotic variables were rarely observed. Weak correlations could be due to large variations in nematode counts resulting from soil population changes that occurred during the sampling period.

This survey identified Pratylenchus spp. and $M$. hapla as the most important nematode parasites in Quebec strawberry and raspberry plantations. Most raspberry fields in all agricultural regions had similar nematode populations. However, strawberry fields in the L'Assomption, Richelieu, Saint-Jean and Québec regions had different nematode populations compared to the Eastern Townships, Mauricie and Nicolet regions. Similarities in the distribution of plant-parasitic nematodes among regions suggests that factors such as cultural practices, including crop rotation, cultivars, and weed management could be involved. The homogeneous group of strawberry fields made of the L'Assomption, Richelieu, Saint-Jean and Québec regions was characterized by a greater diversity of the plant-parasitic nematodes. In these four agricultural regions, growers include various vegetable crops such as corn (Zea mays L.) and potato (Solanum tuberosum L.) in their rotation program, rather than small grains or buckwheat (Fagopyrum esculentum $\mathrm{L}$.)which are predominantly used in the three other producing areas.

Because cultural practices within each agricultural region have remained basically unchanged for the last $10 \mathrm{yr}$, we 

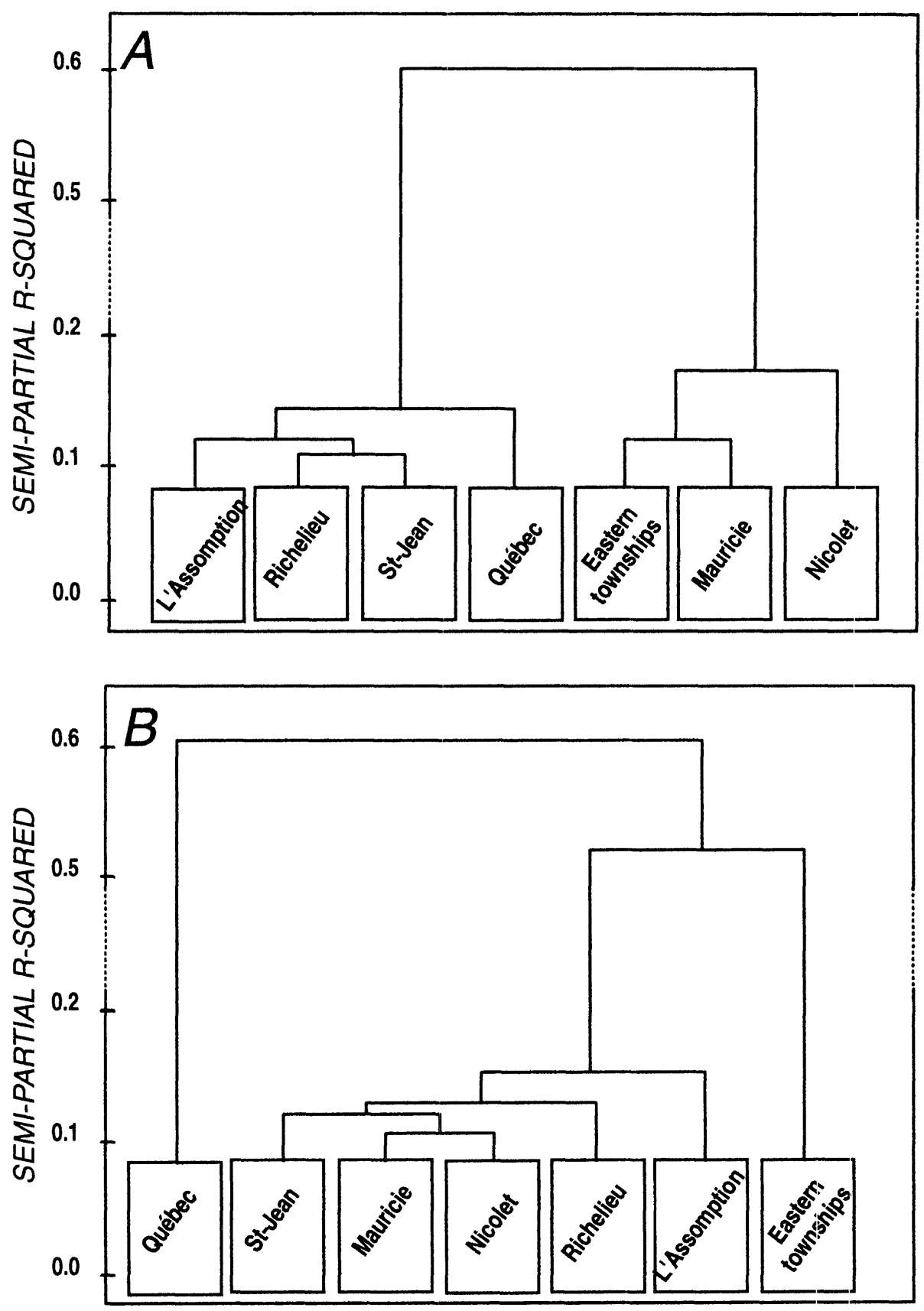

Figure 1. Ward minimum variance cluster analysis based on genera and nematode number collected from (A) strawberry and (B) raspberry fields of seven agricultural regions in Quebec. 
believe that this survey provides a general and realistic representation of the nematode distribution in small fruit production areas of the province of Quebec. The redistribution of some plant-parasitic nematodes from contaminated transplants remains possible since the Quebec certification program does not take nematodes into account.

The importance of these nematodes in strawberry and raspberry fields has not been evaluated yet. More intensive samplings and yield estimates are required to have a better understanding of the relative importance of the plantparasitic nematodes in small fruit production.

\section{REFERENCES}

Bélair, G. 1991. Effects of preplant soil fumigation on nematode population densities and on growth and yield of raspberry. Phytoprotection 72: 21-25.

Bouyoucos, G.J. 1962. Hydrometer method improved for making particle size analysis of soils. Agron. J. 54: 464-465.

Kimpinski, J. 1985. Nematodes in strawberries on Prince Edward Island, Canada. Plant Dis. 69: 105-107.

McElroy, F.D. 1972. Nematodes of tree fruits and small fruits. Pages 335-376 in J.M. Webster (ed.), Economic nematology. Acad. Press, New York.

McKeague, J.A. 1977. Manuel de méthodes d'échantillonnage et d'analyse des sols. Comité canadien de pédologie, Soil Research Institute, Agriculture Canada, Ottawa. 250 pp.
Meloche, F., J.-G. Pilon, G. Mailloux, and T.C. Vrain. 1980. Inventaire des problèmes entomologiques et nématologiques dans les plantations de tabac jaune au Québec. Ann. Soc. Entomol. Que. 25: 81-89.

Proctor, J.R., and C.F. Marks. 1974. The determination of normalizing transformations for nematode count data from soil samples and of efficient sampling schemes. Nematologica 20: 395-406.

Santerre, J., and R. Lévesque. 1982. Inventaire de nématodes phytoparasites dans des cultures de plantes fourragères au Québec: 1973 à 1978. Can. Plant Dis. Surv. 62: 13-19.

SAS Institute Inc. 1988. SAS/STAT User's guide: release 6.03. SAS Institute Inc. Cary, North Carolina. 1029 pp.

Statistics Canada. 1992. Fruit and vegetable production. Ministry of supply and services Canada 1992, catalogue 22-003, vol. $61, \mathrm{n}^{\circ} 2,32 \mathrm{pp}$.

Townshend, J.L. 1963. A modification and evaluation of the apparatus for the Oostenbrink direct cottonwool filter extraction method. Nematologica 9: 106-110.

Vrain, T.C., and M. Dupré. 1982. Distribution des nématodes phytoparasites dans les sols maraîchers du sud-ouest du Québec. Phytoprotection 63: 79-85.

Vrain, T.C., and G.L. Rousselle. 1980. Distribution of plant-parasitic nematodes in Quebec apple orchards. Plant Dis. 64: 582-583.

Willis, C.B., J.L. Townshend, R.V. Anderson, J. Kimpinski, R.H. Mulvey, J.W. Potter, J. Santerre, and L.Y. Wu. 1976. Species of plant-parasitic nematodes associated with forage crops in Eastern Canada. Plant Dis. Rep. 60: 207-210. 